\title{
Association of polymorphic markers of genes FTO, KCNJ11, CDKAL1, SLC3OA8, and CDKN2B with type 2 diabetes mellitus in the Russian population
}

\author{
Aleksey G Nikitin ${ }^{1}$ ， Viktor Y Potapov ${ }^{2}$ ， Olga I Brovkina ${ }^{1}$ ， Ekaterina $\mathbf{O}$ Koksharova ${ }^{3}$ ， Dmitry S Khodyrev ${ }^{1}$, \\ Yury I Philippov Corresp., 3 , Marina S Michurova ${ }^{3}$, Minara S Shamkhalova ${ }^{4}$, Olga K Vikulova ${ }^{3,5}$, Svetlana A \\ Smetanina ${ }^{6}$, Lyudmila A Suplotova ${ }^{6}$, Irina V Kononenko ${ }^{3,5}$, Viktor Y Kalashnikov ${ }^{3}$, Olga M. Smirnova ${ }^{3,5}$, \\ Alexander Y Mayorov ${ }^{7,8}$, Valery V Nosikov ${ }^{9}$, Alexander V Averyanov ${ }^{1}$, Marina V Shestakova ${ }^{5,10}$ \\ ${ }^{1}$ Federal Research Clinical Center for Specialized Types of Health Care and Medical Technologies of Federal Medical and Biology Agency, Moscow, Russian \\ Federation \\ 2 Clinic of New Medical Technologies "Archimedes", Moscow, Russian Federation \\ 3 Endocrinology Research Centre, Moscow, Russian Federation \\ 4 Department of Diabetic Nephropathy, Endocrinology Research Centre, Moscow, Russian Federation \\ 5 I.M.Sechenov First Moscow State Medical University, Moscow, Russian Federation \\ 6 Tyumen State Medical University, Tyumen, Russian Federation \\ 7 Diabetes Institution, Endocrinology Research Centre, Moscow, Russian Federation \\ 8 Department of Endocrinology and Diabetology, I.M.Sechenov First Moscow State Medical University, Moscow, Russian Federation \\ 9 State Research Institute of Genetics and Selection of Industrial Microorganisms, Moscow, Russian Federation \\ 10 Endocrinology Research Centre, Diabetes Institute, Moscow, Russian Federation \\ Corresponding Author: Yury I Philippov \\ Email address: yuriyivanovich@gmail.com
}

Background. The association of type 2 diabetes mellitus (T2DM) with the KCNJ11, CDKAL1, SLC30A8, CDKN2B, and FTO genes in the Russian population has not been well studied. In this study, we analysed the population frequencies of polymorphic markers of these genes. Methods. The study included 862 patients with T2DM and 443 control subjects of Russian origin. All subjects were genotyped for 10 single nucleotide polymorphisms (SNPs) of the genes using real-time PCR (TaqMan assays). HOMA-IR and HOMA- $\beta$ were used to measure insulin resistance and $\beta$-cell secretory function, respectively. Results. The analysis of the frequency distribution of polymorphic markers for genes KCNJ11, CDKAL1, SLC30A8 and CDKN2B showed statistically significant associations with T2DM in the Russian population. The association between the FTO gene and T2DM was not statistically significant. The polymorphic markers rs5219 of the KCNJ11 gene, rs13266634 of the SLC30A8 gene, rs10811661 of the CDKN2B gene and rs9465871, rs7756992 and rs10946398 of the CDKAL1 gene showed a significant association with impaired glucose metabolism or impaired $\beta$-cell function. Conclusion. In the Russian population, genes, which affect insulin synthesis and secretion in the $\beta$-cells of the pancreas, play a central role in the development of T2DM. 


\section{Association of polymorphic markers of genes FTO, KCNJ11, CDKAL1,}

$2 S L C 30 A 8$, and $C D K N 2 B$ with type 2 diabetes mellitus in the Russian

\section{3 population}

5 Alexey G. Nikitin ${ }^{1}$, Viktor A. Potapov², Olga I. Brovkina ${ }^{1}$, Ekaterina O. Koksharova ${ }^{3}$, Dmitry

6 S. Khodyrev 5 , Yury I. Philippov ${ }^{3}$, Marina S. Michurova ${ }^{3}$, Minara S. Shamhalova ${ }^{3}$, Olga K.

7 Vikulova ${ }^{3,7}$, Svetlana A. Smetanina ${ }^{4}$, Lyudmila N. Suplotova ${ }^{4}$, Irina V. Kononenko ${ }^{3,6}$, Viktor Y.

8 Kalashnikov ${ }^{3}$, Olga M. Smirnova ${ }^{3,6}$, Aleksander Y. Mayorov ${ }^{3,6}$, Valery V. Nosikov ${ }^{5}$, Alexander

9 V. Averyanov ${ }^{1}$, Marina V. Shestakova ${ }^{3,6}$

$11{ }^{1}$ Federal research Clinical center for specialized types of health care and medical technologies of

12 Federal Medical and Biology Agency; 28, Orekhovy boulevard, Moscow, 115682, Russian

13 Federation

$14{ }^{2}$ Clinic of New Medical Technologies 'Archimedes'; 49, Bolshaya Semenovskaya st., 107023

15 Moscow, Russian Federation

16 32Endocrinology Research Centre; 11 Dm. Ulyanova street, Moscow, 117036, Russian

17 Federation;

18 4Tyumen State Medical Academy; 54 Odesskaya Str., Tyumen, 625 023, Russian Federation.

19 5State Research Institute of Genetics and Selection of Industrial Microorganisms; 1, 1-st

20 Dorozhny proezd, Moscow, 113545, Russian Federation

21 '6.M.Sechenov First Moscow State Medical University; 8-2 Trubetskaya st., Moscow 119991,

22 Russian Federation 
24 Corresponding author: Yury I. Philippov, Diabetes Institution, Endocrinology Research

25 Centre, 117036, ul. Dmitry Ulyanov, 11, Moscow, Russian Federation: e-mail:

26 yuriyivanovich@gmail.com

\section{Abstract}

Background. The association of type 2 diabetes mellitus (T2DM) with the KCNJ11, CDKAL1, SLC30A8, CDKN2B, and FTO genes in the Russian population has not been well studied. In this study, we analysed the population frequencies of polymorphic markers of these genes.

Methods. The study included 862 patients with T2DM and 443 control subjects of Russian origin. All subjects were genotyped for 10 single nucleotide polymorphisms (SNPs) of the genes using real-time PCR (TaqMan assays). HOMA-IR and HOMA- $\beta$ were used to measure insulin resistance and $\beta$-cell secretory function, respectively.

Results. The analysis of the frequency distribution of polymorphic markers for genes KCNJ11,

CDKAL1, SLC30A8 and CDKN2B showed statistically significant associations with T2DM in the

Russian population. The association between the FTO gene and T2DM was not statistically significant. The polymorphic markers $r s 5219$ of the KCNJ11 gene, rs 13266634 of the SLC30A8 gene, $r s 10811661$ of the $C D K N 2 B$ gene and $r s 9465871, r s 7756992$ and $r s 10946398$ of the

$42 \beta$-cell function.

43 Conclusion. In the Russian population, genes, which affect insulin synthesis and secretion in the $44 \beta$-cells of the pancreas, play a central role in the development of T2DM.

\section{Introduction}


47 Diabetes mellitus is a group of metabolic diseases characterised by chronic hyperglycemia

48 resulting from impaired insulin secretion, resistance to insulin, or both. Chronic hyperglycemia,

49 due to underlying diabetes, is accompanied by impairment or dysfunction of various organs,

50 particularly the eyes, kidneys, nerves, heart and blood vessels.

51 Type 2 diabetes mellitus (T2DM) is 10 times more common than type 1 diabetes mellitus. An

52 epidemic of T2DM is occurring in every country of the world, particularly in industrialised

53 countries. The prevalence of the disease varies in different regions, depending on the ethnicity of

54 the population. According to the World Health Organization, T2DM is present in $3 \%-6 \%$ of the

55 population in European countries, $5 \%$ of the population in the United States, $10 \%$ of African

56 Americans, 24\% of Americans of Mexican origin and 35\% of the population of Micronesia and

57 Polynesia [1].

58 The causes of T2DM pathogenesis include: insulin resistance, impairment of insulin secretion, an

59 increase in the amount of glucose produced by the liver, genetic susceptibility, sedentary lifestyle

60 and excessive caloric intake that leads to obesity. Heredity undoubtedly plays a crucial role in the

61 development of T2DM, with lifestyle exacerbating genetically determined insulin resistance (IR)

$62[2]$.

63 T2DM has a polygenetic nature, i.e. the clinical phenotype is a result of the effects of several

64 genetic loci [3]. Currently, approximately 70 genes have been identified whose variants

65 predispose one to the development of T2DM [4, 5]. However, susceptibility varies across

66 populations due to ethnic differences in the polymorphisms, variations in the structure of the

67 haplotypes/linkage disequilibrium blocks and the influence of non-genetic factors. These genes

68 can be divided into two types based upon their contribution to development of diabetes: genes

69 associated with the impairment of development, growth, proliferation and functioning of the $\beta$ - 
70 cells of the pancreas, and genes that affect the development of insulin resistance in peripheral

71 tissues, such as muscles and liver.

72 Mutations in the KCNJ11 gene, which is located at 2q36, may be associated with the

73 development of T2DM, due to impaired regulation of insulin from the $\beta$-cells of the pancreas.

74 The Kir6.2 protein encoded by this gene is one of two subunits that form a channel for potassium

75 ions [6]. ATP-dependent potassium channels take part in the regulation of insulin secretion

76 through changes in the cell membrane potential of the $\beta$-cells. Mutations in the KCNJ11 gene

77 lead to changes in the structure of the Kir6.2 channel and may lead to neonatal diabetes and

78 congenital hyperinsulinemia [7, 8]. The rs5219 polymorphism in exon 1 of the $K C N J 11$ gene has

79 been associated with the development of T2DM [9]. This polymorphism has been associated

80 with a reduction of insulin secretion in individuals with normal glucose levels [10].

81 Cyclin-dependent kinase inhibitors constitute a family of proteins that regulate cell cycle, cell

82 proliferation and differentiation. Impaired functioning of these proteins is associated with the

83 development of cancer, ischaemic heart disease and diabetes mellitus [11]. The $C D K N 2 A / 2 B$

84 genes, which are located at 9p21, are expressed in all cells, including adipocytes and pancreatic

$85 \beta$-cells. Studies in muscle cells have shown that the protein encoded by the $C D K N 2 B$ gene

86 affects insulin secretion through regulation of the expression of the $E 2 F 1$ gene [12]. The

$87 C D K N 2 A$ gene is likely to be involved in the development of T2DM through an age-dependent

88 reduction in the number and regenerative potential of $\beta$-cells, leading to the overall deterioration

89 of the endocrine function of the pancreas [13].

90 The CDKAL1 gene, located at 6p22.3, is homologous to the CDK5RAP1 inhibitor of the CDK5

91 kinase [14]. It has been shown that CDKAL1 also acts as an inhibitor in pancreatic $\beta$-cells; 
92 CDK5 kinase activity plays a significant role in the efficiency of insulin granule secretion into

93 the bloodstream $[15,16]$.

94 One of the major causes of T2DM development is a reduction in insulin secretion. This process

95 requires the optimal concentration of zinc ions in the $\beta$-cells of the pancreas, which are regulated

96 by type 8 zinc carrier proteins (ZnT8) [17]. ZnT8is encoded by the SLC30A8 gene located near

$978 \mathrm{q} 24.11$. The expression of this gene is most intense in pancreatic $\beta$-cells [18]. The participation

98 of the SLC30A8 gene in the development of T2DM has been substantiated in several large-scale

99 studies [19-21].

100 The FTO gene is located at $16 \mathrm{q} 12.2$. Its function in the development of obesity remains to be

101 determined. The FTO gene is expressed in various tissues, particularly the hypothalamus, liver,

102 muscle tissue, adipocytes and the $\beta$-cells of the pancreas [22]. Its expression in the subcutaneous

103 fat is higher than in other tissues, although its expression in other tissues that affects the body

104 mass index (BMI) [23].

105 This study examined the association of the polymorphic markers of the genes KCNJ11,

$106 S L C 30 A 8, C D K A L 1, C D K N 2 B$ and FTO with type 2 diabetes mellitus in Russia. These

107 polymorphisms have produced controversial results in studies on several European populations.

108 The data in the current literature for these genes is very limited.

109

110 Materials and Methods

111 The study compared 862 patients diagnosed with T2DM (DM2+) to a control group (DM2-)

112 consisting of 443 randomly selected patients showing no signs of T2DM based on clinical and

113 biochemical examinations. Subjects of the DM2+ group were patients at the Endocrinology

114 Research Center (Moscow, Russia) and Tyumen State Medical University (Tyumen, Russia) and 
115 were of European ancestry, based upon the results of a questionnaire. The groups were similar in

116 terms of age and sex (Table 1).

117

118 Table 1. Characteristics of the examined groups

\begin{tabular}{|l|l|l|}
\hline Characteristics & DM2+ $(\mathrm{n}=862)$ & DM2- $(\mathrm{n}=443)$ \\
\hline Age (years) & $60.0 \pm 10.2$ & $54.4 \pm 11.0$ \\
\hline BMI* & $30.5 \pm 5.0$ & $28.7 \pm 4.8$ \\
\hline Basal glucose level (mol/l) & $9.4 \pm 1.3$ & $5.1 \pm 0.7$ \\
\hline Glucose level 2 h after PGTT** (mol/l) & $12.1 \pm 1.4$ & $6.9 \pm 0.8$ \\
\hline Basal insulin level (mU/l) & $14.9 \pm 5.4$ & $10.4 \pm 4.3$ \\
\hline Insulin level 2 h after PGTT** (mU/l) & $93.6 \pm 28.4$ & $41.9 \pm 10.3$ \\
\hline Glycated hemoglobin HBAlc $(\%)$ & $7.4 \pm 1.9 \%$ & - \\
\hline HOMA-b & $47.8 \pm 16.1$ & $94.3 \pm 30.6$ \\
\hline HOMA-IR & $6.7 \pm 1.3$ & $2.8 \pm 1.5$ \\
\hline$*$ BMI-body mass & & \\
\hline
\end{tabular}

* BMI-body mass index

** PGTT-peroral glucose tolerance test

122 Blood glucose and insulin concentrations were measured at baseline and two $\mathrm{h}$ after an oral

123 glucose tolerance test. The homeostasis model assessment of insulin resistance (HOMA-IR) and

124 the homeostasis model assessment of $\beta$-cell function (HOMA- $\beta$ ) indices were calculated for the

125 purpose of evaluating the insulin resistance in tissues and $\beta$-cell function, respectively [24].

126 Genomic DNA was phenol-chloroform extracted from whole blood samples after incubation 
127 with proteinase $\mathrm{K}$ in the presence of $0.1 \%$ sodium dodecyl sulfate using conventional methods $128[25]$.

129 Real-time PCR was used to amplify regions of interest within the target genes. PCR was

130 conducted using 50-100 ng of genomic DNA in $20 \mu \mathrm{L}$ of a reaction mixture containing $70 \mathrm{mM}$

131 Tris-HCI, pH 8.8, $16.6 \mathrm{mM}$ ammonium sulfate, 0.01\% Tween-20, $2 \mathrm{mM}$ magnesium chloride,

$132200 \mathrm{nmol}$ of each dNTP, $500 \mathrm{nmol}$ primers (Evrogen, Russia), $350 \mathrm{nmol}$ of fluorescent probes

133 (DNK-Sintez, Russia) and 1.5 U Taq DNA-polymerase (Evrogen, Russia). Amplification was

134 carried out using an StepOnePlus thermal cycler (Applied Biosystems, CA, USA) using the

135 following conditions: initial denaturation at $95^{\circ} \mathrm{C}$ for two min; 40 cycles of denaturation $\left(94^{\circ} \mathrm{C}\right)$

136 for $10 \mathrm{sec}$, annealing $\left(54^{\circ} \mathrm{C}-66^{\circ} \mathrm{C}\right)$ for $60 \mathrm{sec}$, extension $\left(72^{\circ} \mathrm{C}\right)$ for $10 \mathrm{sec}$. The fluorescent dyes

137 used in the probes were carboxyfluorescein and hexachlorofluorescein, and the fluorescence

138 extinguisher was BHQ-1. The sequences of primers, fluorescent probes and the method for

139 determining the genotypes of the examined loci are presented in supplementary table S1.

140 Designations of polymorphic markers comply with the standards of the dbSNP database

141 (http://www.ncbi.nlm.nih.gov/snp/).

142 The genotype analysis of polymorphic markers of several genes was performed through endpoint

143 fluorescence detection using the built-in tools of the SDS 2.3 software, with a sample considered

144 positive if its quality value was $95 \%$. Samples that failed to meet this quality value were re-

145 analysed (100\% of samples were subjected to genotype analysis). Contingency tables and chi-

146 square tests were used for statistical analyses of the allelic distributions of the SNPs in the DM2+

147 and DM2- groups. Calculations were performed using the calculator for statistical computation

148 in case-control studies [26] and SPSS, ver. 17. For all analyses, $P<0.05$ was considered to be

149 statistically significant. Analysis of variance was used to test for associations between gene 
150 polymorphisms and metabolic characteristics (glucose and insulin levels, HOMA-IR and

151 HOMA- $\beta$ indices).

152 Genes that exhibited no reliable or reproducible data for the Russian population were selected to

153 determine any association. Due to the conflicting results obtained by other researchers, the

154 examination of the entire linkage disequilibrium block in the promoter region of the FTO gene

155 was investigated. HaploView 3.2 was used for the analysis of linkage disequilibrium blocks and

156 selection of polymorphic markers for the FTO gene [27].

157 The local Committee for Ethics of Endocrinology Research Centre (Moscow, Russian

158 Federation) granted ethical approval for the study (Ethical Application Ref: protocol No.14AB

159 on 27-nov-2014).

160

161 Results

162 The prevalence of alleles of polymorphic markers of FTO, KCNJ11, CDKAL1, SLC30A8 and

$163 C D K N 2 B$ in the sample population was not significantly different from the prevalence in a typical

164 European population (data for the European population was obtained from the HapMap (CEU)

165 project, http://hapmap.org). The distribution of alleles in DM2+ and DM2- groups was consistent

166 with the distribution predicted by the Hardy-Weinberg equilibrium, which permitted the use of a

167 multiplicative inheritance model for the analysis of associations between polymorphic markers

168 and metabolic phenotypes [28].

169 Table 2 summarises the results of the analysis of associations of the examined markers with

170 T2DM. The following polymorphic markers showed statistically significant association with

171 T2DM: rs5219 of the KCNJ11 gene, rs 13266634 of the SLC30A8 gene, rs 10811661 of the

$172 C D K N 2 B / 2 A$ gene, $r s 9465871$, rs7756992 and $r s 10946398$ of the CDKAL1 gene. 
Table 2. Comparative analysis of allele and genotype distribution of polymorphic markers of the genes $F T O, K C N J 11$,

\section{CDKAL1, SLC30A8, and CDKN2B}

\begin{tabular}{|c|c|c|c|c|c|c|c|c|c|c|}
\hline \multirow{3}{*}{ Gene } & \multirow{3}{*}{$\begin{array}{c}\text { Polymorphic } \\
\text { marker }\end{array}$} & \multirow{3}{*}{$\begin{array}{c}\text { Genotyp } \\
\text { e }\end{array}$} & \multicolumn{2}{|c|}{$\begin{array}{c}\text { Distribution of } \\
\text { genotypes }\end{array}$} & \multicolumn{6}{|c|}{ Model } \\
\hline & & & DM2+ & DM2- & \multicolumn{2}{|c|}{ Multiplicative } & \multicolumn{2}{|r|}{ Dominant } & \multicolumn{2}{|r|}{ Recessive } \\
\hline & & & $\mathrm{N}=862$ & $\mathrm{~N}=443$ & $p$ & OR $(95 \% C I)$ & $p$ & OR $(95 \% C I)$ & $p$ & OR $(95 \% C I)$ \\
\hline \multirow{2}{*}{ FTO } & $r s 8050136$ & $\begin{array}{l}C / C \\
C / A \\
A / A\end{array}$ & $\begin{array}{c}272 \\
(0,32) \\
527 \\
(0,61) \\
63(0,07)\end{array}$ & $\begin{array}{l}143(0,32) \\
281(0,63) \\
19(0,04)\end{array}$ & 0.1 & $\begin{array}{l}0.97(0.76-1.24) \\
0.91(0.72-1.15) \\
1.76(1.04-2.98)\end{array}$ & 0.79 & $\begin{array}{c}0.97(\mathrm{C} / \mathrm{C})(0.76-1.24) \\
1.04 \\
(\mathrm{C} / \mathrm{A}+\mathrm{A} / \mathrm{A} \text { vs. } \mathrm{C} / \mathrm{C})(0.81- \\
1.32)\end{array}$ & 0.02 & $\begin{array}{c}1.76(\mathrm{~A} / \mathrm{A})(1.04-2.98) \\
0.57(\mathrm{C} / \mathrm{C}+\mathrm{C} / \mathrm{A} \text { vs. } \mathrm{A} / \mathrm{A}) \\
(0.34-0.96)\end{array}$ \\
\hline & $r s 7202116$ & $\begin{array}{l}A / A \\
A / G \\
G / G\end{array}$ & $\begin{array}{c}225 \\
(0,26) \\
468 \\
(0,54) \\
169(0,2)\end{array}$ & $\begin{array}{l}124(0,28) \\
231(0,52) \\
88(0,2)\end{array}$ & 0.72 & $\begin{array}{l}0.91(0.70-1.18) \\
1.09(0.87-1.37) \\
0.98(0.74-1.31)\end{array}$ & 0.47 & $\begin{array}{c}0.91(\mathrm{~A} / \mathrm{A})(0.70-1.18) \\
1.10 \\
(\mathrm{~A} / \mathrm{G}+\mathrm{G} / \mathrm{G} \text { vs. } \mathrm{A} / \mathrm{A}) \\
(0.85-1.42)\end{array}$ & 0.91 & $\begin{array}{c}0.98(\mathrm{G} / \mathrm{G})(0.74-1.31) \\
1.02 \\
(\mathrm{~A} / \mathrm{A}+\mathrm{A} / \mathrm{G} \text { vs. } \mathrm{G} / \mathrm{G}) \\
(0.76-1.36)\end{array}$ \\
\hline
\end{tabular}




\begin{tabular}{|c|c|c|c|c|c|c|c|c|c|c|}
\hline & rs9930506 & $\begin{array}{l}A / A \\
A / G \\
G / G\end{array}$ & $\begin{array}{c}208 \\
(0,24) \\
466 \\
(0,54) \\
188 \\
(0,22)\end{array}$ & $\begin{array}{c}115(0,26) \\
239(0,54) \\
89(0,2)\end{array}$ & 0.67 & $\begin{array}{l}0.91(0.70-1.18) \\
1.00(0.80-1.26) \\
1.11(0.84-1.47)\end{array}$ & 0.47 & $\begin{array}{c}0.91(\mathrm{~A} / \mathrm{A})(0.70-1.18) \\
1.10 \\
(\mathrm{~A} / \mathrm{G}+\mathrm{G} / \mathrm{G} \text { vs. } \mathrm{A} / \mathrm{A}) \\
(0.85-1.43)\end{array}$ & 0.47 & $\begin{array}{c}1.11(\mathrm{G} / \mathrm{G})(0.68-1.20) \\
0.90 \\
(\mathrm{~A} / \mathrm{A}+\mathrm{A} / \mathrm{G} \text { vs. G/G) } \\
(0.84-1.47)\end{array}$ \\
\hline $\begin{array}{c}\text { KCNJ1 } \\
1\end{array}$ & $r s 5219$ & $\begin{array}{l}\text { Glu/Glu } \\
\text { Glu/Lys } \\
\text { Lys/Lys }\end{array}$ & $\begin{array}{c}174(0,2) \\
486 \\
(0,56) \\
202 \\
(0,23)\end{array}$ & $\begin{array}{l}124(0,28) \\
246(0,56) \\
73(0,16)\end{array}$ & $\begin{array}{c}0.000 \\
7\end{array}$ & $\begin{array}{l}0.65(0.50-0.85) \\
1.04(0.82-1.30) \\
1.55(1.15-2.09)\end{array}$ & 0.001 & $\begin{array}{c}0.65 \text { (Glu/Glu) } \\
1.54(0.50-0.85) \\
\text { (Glu/Lys+Lys/Lys vs. } \\
\text { Glu/Glu) (1.18-2.01) }\end{array}$ & 0.004 & $\begin{array}{c}\text { 1.55(Lys/Lys) (0.48-0.87) } \\
0.64 \\
\text { (Glu/Glu+Glu/Lys vs. } \\
\text { Lys/Lys) }(1.15-2.09)\end{array}$ \\
\hline $\begin{array}{c}S L C 30 A \\
8\end{array}$ & $r s 13266634$ & $\begin{array}{l}C / C \\
C / T \\
T / T\end{array}$ & $\begin{array}{c}449 \\
(0,52) \\
340 \\
(0,39) \\
73(0,08)\end{array}$ & $\begin{array}{l}268(0,6) \\
154(0,35) \\
21(0,05)\end{array}$ & 0.004 & $\begin{array}{l}0.71(0.56-0.90) \\
1.22(0.96-1.55) \\
1.86(1.13-3.06)\end{array}$ & 0.004 & $\begin{array}{c}0.71(\mathrm{C} / \mathrm{C})(0.56-0.90) \\
1.41 \\
(\mathrm{C} / \mathrm{T}+\mathrm{T} / \mathrm{T} \text { vs. } \mathrm{C} / \mathrm{C}) \\
(1.12-1.78)\end{array}$ & 0.01 & $\begin{array}{c}1.86(\mathrm{~T} / \mathrm{T})(1.13-3.06) \\
0.54 \\
(\mathrm{C} / \mathrm{C}+\mathrm{C} / \mathrm{T} \text { vs. } \mathrm{T} / \mathrm{T}) \\
(0.33-0.89)\end{array}$ \\
\hline
\end{tabular}




\begin{tabular}{|c|c|c|c|c|c|c|c|c|c|c|}
\hline $\begin{array}{c}C D K N 2 \\
B\end{array}$ & $r s 10811661$ & $\begin{array}{l}T / T \\
C / T \\
C / C\end{array}$ & $\begin{array}{c}285 \\
(0,33) \\
405 \\
(0,47) \\
172(0,2)\end{array}$ & $\begin{array}{l}209(0,47) \\
187(0,42) \\
47(0,11)\end{array}$ & $\begin{array}{c}1.0 \mathrm{E}- \\
7\end{array}$ & $\begin{array}{c}0.55(0.44-0.70) \\
1.21(0.96-1.53) \\
2.10(1.49- \\
2.97)\end{array}$ & $\begin{array}{c}7.0 \mathrm{E}- \\
7\end{array}$ & $\begin{array}{c}0.55(\mathrm{~T} / \mathrm{T})(0.44-0.70) \\
1.81 \\
(\mathrm{~T} / \mathrm{C}+\mathrm{C} / \mathrm{C})(1.43-2.29)\end{array}$ & $\begin{array}{c}2.0 \mathrm{E}- \\
5\end{array}$ & $\begin{array}{c}2.10(\mathrm{C} / \mathrm{C})(1.49-2.97) \\
0.48 \\
(\mathrm{~T} / \mathrm{T}+\mathrm{T} / \mathrm{C})(0.34-0.67)\end{array}$ \\
\hline \multirow[t]{2}{*}{$\begin{array}{c}C D K A L \\
1\end{array}$} & $r s 7756992$ & $\begin{array}{l}A / A \\
A / G \\
G / G\end{array}$ & $\begin{array}{c}390 \\
(0,45) \\
329 \\
(0,38) \\
143 \\
(0,17)\end{array}$ & $\begin{array}{l}235(0,53) \\
169(0,38) \\
39(0,09)\end{array}$ & $\begin{array}{c}0.000 \\
3\end{array}$ & $\begin{array}{l}0.73(0.58-0.92) \\
1.00(0.79-1.27) \\
2.06(1.42-3.00)\end{array}$ & 0.008 & $\begin{array}{c}0.73(\mathrm{~A} / \mathrm{A})(0.58-0.92) \\
1.37 \\
(\mathrm{~A} / \mathrm{G}+\mathrm{G} / \mathrm{G} \text { vs. } \mathrm{A} / \mathrm{A}) \\
(1.09-1.72)\end{array}$ & $\begin{array}{c}0.000 \\
1\end{array}$ & $\begin{array}{c}2.06(\mathrm{G} / \mathrm{G})(1.42-3.00) \\
0.49(\mathrm{~A} / \mathrm{A}+\mathrm{A} / \mathrm{G} \text { vs. } \mathrm{G} / \mathrm{G}) \\
(0.33-0.71)\end{array}$ \\
\hline & rs 9465871 & $\begin{array}{l}C / C \\
C / T \\
T / T\end{array}$ & $\begin{array}{c}259(0,3) \\
468 \\
(0,54) \\
135 \\
(0,16)\end{array}$ & $\begin{array}{c}190(0,43) \\
204(0,46) \\
49(0,11)\end{array}$ & $\begin{array}{c}1.0 \mathrm{E}- \\
5\end{array}$ & $\begin{array}{l}0.57(0.45-0.73) \\
1.39(1.11-1.75) \\
1.49(1.05-2.12)\end{array}$ & $\begin{array}{c}4.0 \mathrm{E}- \\
6\end{array}$ & $\begin{array}{c}0.57(\mathrm{C} / \mathrm{C})(0.45-0.73) \\
1.75 \\
(\mathrm{C} / \mathrm{T}+\mathrm{T} / \mathrm{T} \text { vs. } \mathrm{C} / \mathrm{C}) \\
(1.38-2.22)\end{array}$ & 0.02 & $\begin{array}{c}1.49(\mathrm{~T} / \mathrm{T})(0.47-0.95) \\
0.67 \\
(\mathrm{C} / \mathrm{C}+\mathrm{C} / \mathrm{T})(1.05-2.12)\end{array}$ \\
\hline
\end{tabular}




\begin{tabular}{|c|c|c|c|c|c|c|c|c|c|}
\hline$r s 7754840$ & $\begin{array}{l}C / C \\
C / G \\
G / G\end{array}$ & $\begin{array}{c}440 \\
(0,51) \\
379 \\
(0,44) \\
43(0,05)\end{array}$ & $\begin{array}{l}205(0,46) \\
213(0,48) \\
25(0,06)\end{array}$ & 0.26 & $\begin{array}{l}1.21(0.96-1.52) \\
0.85(0.67-1.07) \\
0.88(0.53-1.46)\end{array}$ & 0.61 & $\begin{array}{c}0.88(\mathrm{G} / \mathrm{G})(0.53-1.46) \\
1.14 \\
(\mathrm{C} / \mathrm{C}+\mathrm{C} / \mathrm{G} \text { vs. G/G) } \\
(0.69-1.89)\end{array}$ & 0.1 & $\begin{array}{c}1.21(\mathrm{C} / \mathrm{C})(0.96-1.52) \\
0.83 \\
(\mathrm{C} / \mathrm{G}+\mathrm{G} / \mathrm{G})(0.66-1.04)\end{array}$ \\
\hline rs 10946398 & $\begin{array}{l}A / A \\
A / C \\
C / C\end{array}$ & $\begin{array}{c}500 \\
(0,58) \\
293 \\
(0,34) \\
69(0,08)\end{array}$ & $\begin{array}{l}297(0,67) \\
124(0,28) \\
22(0,05)\end{array}$ & 0.004 & $\begin{array}{l}0.68(0.53-0.86) \\
1.32(1.03-1.70) \\
1.67(1.02-2.73)\end{array}$ & 0.002 & $\begin{array}{c}0.68(\mathrm{~A} / \mathrm{A})(0.53-0.86) \\
1.47 \\
(\mathrm{~A} / \mathrm{C}+\mathrm{C} / \mathrm{C} \text { vs. } \mathrm{A} / \mathrm{A})(1.16- \\
1.87)\end{array}$ & 0.04 & $\begin{array}{c}1.67(\mathrm{C} / \mathrm{C})(1.02-2.73) \\
0.60 \\
(\mathrm{~A} / \mathrm{A}+\mathrm{A} / \mathrm{C} \text { vs. } \mathrm{C} / \mathrm{C})(0.37- \\
0.98)\end{array}$ \\
\hline
\end{tabular}


177 Table 3 summarises the results of the association analysis for the examined SNPs and metabolic

178 indicators of glucose intolerance and $\beta$-cell dysfunction. All results with $P<0.05$ for at least one

179 indicator are shown. The following polymorphic markers showed a significant association with

180 impaired glucose metabolism or impaired $\beta$-cell function: rs5219 of the KCNJ11 gene,

$181 r s 13266634$ of the $S L C 30 A 8$ gene, $r s 10811661$ of the $C D K N 2 B$ gene and $r s 9465871, r s 7756992$

182 and $r s 10946398$ of the CDKAL1 gene. 
184 Table 3. Analysis of associations of polymorphic markers of the genes FTO, KCNJ11, CDKAL1, SLC30A8, and CDKN2B with the 185 metabolic indicators of glucose tolerance and $\beta$-cell function

\begin{tabular}{|c|c|c|c|c|c|c|c|c|}
\hline \multirow{3}{*}{ Gene } & \multirow{3}{*}{$\begin{array}{l}\text { Polymorphic } \\
\text { marker }\end{array}$} & \multirow{3}{*}{$\begin{array}{c}\text { Genotyp } \\
\text { e }\end{array}$} & \multicolumn{3}{|c|}{ Insulin level $2 \mathrm{~h}$ after PGGT** (mU/l) } & \multicolumn{3}{|c|}{ НОМА- $\beta$} \\
\hline & & & DM2+ & DM2- & $p$ & DM2+ & DM2- & $p$ \\
\hline & & & $\mathrm{N}=862$ & $\mathrm{~N}=443$ & $\begin{array}{c}(D M+/ D M \\
-)\end{array}$ & $\mathrm{N}=862$ & $\mathrm{~N}=443$ & $\begin{array}{c}(D M+/ D M \\
-)\end{array}$ \\
\hline \multirow{2}{*}{ FTO } & $r s 8050136$ & $\begin{array}{l}C / C \\
C / A \\
A / A\end{array}$ & $\begin{array}{l}80.9 \pm 24.9 \\
78.7 \pm 32.2 \\
78.9 \pm 28.2\end{array}$ & $\begin{array}{l}51.2 \pm 24.9 \\
49.8 \pm 25.2 \\
49.1 \pm 26.3\end{array}$ & $-1-$ & $\begin{array}{l}59.2 \pm 24.3 \\
56.3 \pm 22.4 \\
60.1 \pm 26.7\end{array}$ & $\begin{array}{r}99.2 \pm 36.1 \\
99.3 \pm 36.2 \\
100.1 \pm 31.7\end{array}$ & $-1-$ \\
\hline & $r s 7202116$ & $\begin{array}{l}A / A \\
A / G \\
G / G\end{array}$ & $\begin{array}{l}79.7 \pm 26.9 \\
80.3 \pm 31.2 \\
78.2 \pm 28.7\end{array}$ & $\begin{array}{l}49.1 \pm 23.8 \\
49.2 \pm 24.1 \\
53.2 \pm 27.2\end{array}$ & $-1-$ & $\begin{array}{l}60.1 \pm 24.8 \\
59.2 \pm 22.1 \\
59.3 \pm 26.2\end{array}$ & $\begin{array}{r}101.2 \pm 38.3 \\
99.6 \pm 35.7 \\
100.2 \pm 36.4\end{array}$ & $-1-$ \\
\hline
\end{tabular}




\begin{tabular}{|c|c|c|c|c|c|c|c|c|}
\hline & rs9930506 & $\begin{array}{l}A / A \\
A / G \\
G / G\end{array}$ & $\begin{array}{l}78.5 \pm 28.2 \\
81.2 \pm 30.2 \\
82.1 \pm 29.0\end{array}$ & $\begin{array}{l}49.8 \pm 23.8 \\
52.5 \pm 26.5 \\
50.9 \pm 24.1\end{array}$ & $-1-$ & $\begin{array}{l}61.2 \pm 21.5 \\
59.9 \pm 22.3 \\
59.5 \pm 25.6\end{array}$ & $\begin{array}{l}100.1 \pm 39.7 \\
99.2 \pm 39.2 \\
98.9 \pm 37.1\end{array}$ & $-1-$ \\
\hline $\begin{array}{c}\text { KCNJ1 } \\
1\end{array}$ & $r s 5219$ & $\begin{array}{l}\text { Glu/Glu } \\
\text { Glu/Lys } \\
\text { Lys/Lys }\end{array}$ & $\begin{array}{l}80.1 \pm 33.5 \\
88.8 \pm 32.2 \\
89.4 \pm 31.2\end{array}$ & $\begin{array}{l}44.9 \pm 19.2 \\
53.2 \pm 21.4 \\
54.2 \pm 23.2\end{array}$ & $0.020 / 0.044$ & $\begin{array}{l}46.2 \pm 20.8 \\
43.7 \pm 22.9 \\
43.7 \pm 22.9\end{array}$ & $\begin{array}{l}99.6 \pm 37.5 \\
84.7 \pm 38.2 \\
81.2 \pm 39.9\end{array}$ & $-/ 0.020$ \\
\hline $\begin{array}{c}S L C 30 A \\
8\end{array}$ & $r s 13266634$ & $\begin{array}{l}C / C \\
C / T \\
T / T\end{array}$ & $\begin{array}{l}78.4 \pm 30.7 \\
88.9 \pm 31.2 \\
89.8 \pm 30.9\end{array}$ & $\begin{array}{l}43.2 \pm 17.7 \\
49.2 \pm 22.7 \\
53.6 \pm 19.1\end{array}$ & $0.030 / 0.018$ & $\begin{array}{l}48.3 \pm 23.3 \\
52.2 \pm 26.7 \\
51.7 \pm 22.5\end{array}$ & $\begin{array}{l}92.9 \pm 41.1 \\
96.2 \pm 42.3 \\
93.6 \pm 43.5\end{array}$ & $-1-$ \\
\hline $\begin{array}{c}C D K N 2 \\
B\end{array}$ & rs 10811661 & $\begin{array}{l}T / T \\
C / T \\
C / C\end{array}$ & $\begin{array}{l}85.9 \pm 31.4 \\
82.4 \pm 30.3 \\
71.2 \pm 34.5\end{array}$ & $\begin{array}{c}49.4 \pm 17.6 \\
48.3 \pm 16.5 \\
48.7 \pm 15.8\end{array}$ & $0.035 /-$ & $\begin{array}{l}47.9 \pm 21.2 \\
44.2 \pm 20.1 \\
32.1 \pm 18.5\end{array}$ & $\begin{array}{l}106.1 \pm 34.7 \\
95.2 \pm 33.2 \\
90.8 \pm 29.9\end{array}$ & $0.021 / 0.042$ \\
\hline $\begin{array}{c}C D K A L \\
1\end{array}$ & $r s 7756992$ & $\begin{array}{l}A / A \\
A / G \\
G / G\end{array}$ & $\begin{array}{l}82.4 \pm 30.5 \\
79.9 \pm 31.4 \\
71.8 \pm 29.1\end{array}$ & $\begin{array}{l}50.6 \pm 20.1 \\
49.1 \pm 19.4 \\
46.1 \pm 21.1\end{array}$ & $0.033 / 0.045$ & $\begin{array}{l}60.8 \pm 14.5 \\
56.5 \pm 21.0 \\
50.5 \pm 21.9\end{array}$ & $\begin{array}{c}105.8 \pm 38.8 \\
99.9 \pm 44.1 \\
96.6 \pm 36.2\end{array}$ & $0.023 / 0.041$ \\
\hline
\end{tabular}




\begin{tabular}{|c|c|c|c|c|c|c|c|}
\hline$r s 9465871$ & $\begin{array}{l}C / C \\
C / T \\
T / T\end{array}$ & $\begin{array}{l}85.1 \pm 30.5 \\
80.5 \pm 33.3 \\
71.8 \pm 29.1\end{array}$ & $\begin{array}{l}49.3 \pm 24.1 \\
46.4 \pm 22.9 \\
40.2 \pm 19.2\end{array}$ & $0.025 / 0.035$ & $\begin{array}{l}53.0 \pm 20.5 \\
49.5 \pm 23.9 \\
42.7 \pm 18.9\end{array}$ & $\begin{array}{l}104.2 \pm 48.2 \\
97.0 \pm 40.1 \\
96.0 \pm 35.6\end{array}$ & $0.021 / 0.041$ \\
\hline rs 7754840 & $\begin{array}{l}C / C \\
C / G \\
G / G\end{array}$ & $\begin{array}{l}80.1 \pm 25.7 \\
79.9 \pm 32.9 \\
79.7 \pm 26.1\end{array}$ & $\begin{array}{l}50.6 \pm 22.6 \\
49.1 \pm 22.7 \\
51.1 \pm 25.5\end{array}$ & $-1-$ & $\begin{array}{l}60.4 \pm 18.3 \\
59.3 \pm 20.4 \\
58.7 \pm 24.7\end{array}$ & $\begin{array}{l}101.4 \pm 39.4 \\
99.3 \pm 42.7 \\
101.8 \pm 33.9\end{array}$ & $-/-$ \\
\hline$r s 10946398$ & $\begin{array}{l}A / A \\
A / C \\
C / C\end{array}$ & $\begin{array}{l}85.7 \pm 32.8 \\
83.2 \pm 35.6 \\
72.4 \pm 32.9\end{array}$ & $\begin{array}{l}48.2 \pm 17.7 \\
46.5 \pm 20.2 \\
40.4 \pm 18.5\end{array}$ & $0.032 / 0.047$ & $\begin{array}{l}60.2 \pm 19.9 \\
60.4 \pm 21.3 \\
59.5 \pm 24.2\end{array}$ & $\begin{array}{c}101.4 \pm 39.4 \\
99.3 \pm 42.7 \\
101.8 \pm 33.9\end{array}$ & $-1-$ \\
\hline
\end{tabular}




\section{Discussion}

188 The KCNJ11 gene contains the SNP rs5219 in exon 1 (substitution $\mathrm{G} \rightarrow \mathrm{A}$ ), which leads to the

189 substitution of Glu for Lys at position 23. Although several studies on the association of this

190 polymorphism with T2DM in different populations have produced conflicting results [29], more

191 recent studies have found an association between this polymorphic marker and the disease [30].

192 Increased numbers of patients in study populations have revealed an association between this

193 polymorphic marker and the T2DM development [31-37]. Despite the fact that this association

194 was found by other investigators [38], the $K 23$ allele has been associated with the increased risk

195 of T2DM development in many European (odds ratio $(\mathrm{OR})=1.23)$ and Asian populations $(\mathrm{OR}=$

196 1.26) [39]. An analysis of the distribution of frequencies, alleles and genotypes of the

197 polymorphic marker $r s 5219$ of the $K C N J 11$ gene showed statistically significant differences

198 between the DM2+ and DM2- groups in the Russian population. The presence of the Lys/Lys

199 genotype increased the risk of T2DM development $(\mathrm{OR}=1.55)$, whereas that of the $G l u / G l u$

200 genotype reduced development $(\mathrm{OR}=0.65)$.

201 The protein of the SLC $30 A 8$ gene plays a direct role in the maturation and secretion of insulin

202 granules [17]. Previous work demonstrated that changes in this gene are associated with T2DM

203 development in several populations [20, 21, 29]. The SNP rs 13266634, located in exon 8, has the

204 most distinct association with diabetes. This SNP results in the replacement of arginine (R) by

205 tryptophan $(\mathrm{W})(\mathrm{OR}=1.12$ in Caucasians $)$ at position 325 of the protein sequence. The

206 carriership of the 'predisposing-to-disease' allele $R 325$ is associated with a reduction in insulin

207 secretion (also as a response to glucose stimulation [40]) and impairment of the transformation of

208 proinsulin into insulin [41]. Our study demonstrated an association between the SNP rs 13266634 
209 of the $S L C 30 A 8$ gene with T2DM, with the $T / T$ genotype as the predisposing genotype (OR = $210 \quad 1.86)$

211 Previous studies have shown that the $C D K N 2 B / 2 A$ gene plays a dual role in the deterioration of

212 insulin secretion. The protein produce of this gene plays an indirect role in the regulation of

$213 K C N J 11$ gene expression by regulating $E 2 F 1$ gene expression, which in turn regulates $K C N J 11$

214 gene expression [11]. It also participates in the regulation of $\beta$-cell proliferation [42]. Studies on

215 the Chinese [43], African-American [44], Japanese [45] and several European populations [46-

$21648]$ have confirmed that polymorphisms at the $C D K N 2 A / 2 B$ locus are associated with T2DM

217 development. The rs 10811661 marker has the strongest association with diabetes in European

218 populations $(\mathrm{OR}=1.19)[47]$. We found that this polymorphic marker also had a strong

219 association with T2DM in the Russian population $(\mathrm{OR}=2.10)$.

220 Several polymorphisms ( $r s 7756992$, rs 7754840 and $r s 10946398)$ in the CDKAL1 gene have

221 exhibited association with T2DM (OR up to 1.15 in populations with European ethnicity) [49].

222 Insulin secretion is reduced in response to glucose in carriers of the risk alleles rs 7756992 and

$223 r$ rs10946398 of the CDKAL1 gene [50]. To date, several SNPs have been identified in the

$224 C D K A L 1$ gene that exhibit an association with low insulin secretion in individuals with and

225 without T2DM, depending upon the population [51-54]. Three (rs 9465871, rs 7756992 and

$226 r s$ 10946398) out of the four examined polymorphic markers exhibited association with T2DM

227 development in our population.

228 Insulin resistance is a major factor for T2DM development. An increase in body mass index

229 (BMI) and fat mass contributes to the development and aggravation of immune resistance [23,

$23055]$. Recent population studies have demonstrated that people who are homozygous for allele $A$

231 of the $F T O$ gene variant $r s 9939609$ have a higher BMI, weigh $3 \mathrm{~kg}$ more on average and are 
232 twice as likely to become obese compared to individuals homozygous for the protective allele

$233 T / T$ genotype [56-60]. The presence of the protective $T$ allele leads to increased lipolytic activity

234 of adipocytes, thus reducing fat mass [61]. Examinations of many patient populations have

235 shown certain correlations between increased BMI, obesity and the presence of several SNPs,

236 most notably $r s 9939609$ in intron 1 of the $F T O$ gene (OR $=1.42$ in individuals with European

237 ethnicity) [62].

238 We studied the effect of the polymorphic markers $r s 8050136$, rs 7202116 and $r s 9930506$ (tag-

239 SNP, characterising the linkage disequilibrium block in the promoter region) of the FTO gene on

240 T2DM development. The analysis showed no statistically significant differences in the

241 distribution of these polymorphic markers between the DM2+ and DM2- groups.

242 Based on these results, it can be concluded that the genes, KCNJ11, SLC30A8, CDKN2B and

$243 C D K A L 1$, affect the level of insulin synthesis and secretion in the $\beta$-cells of the pancreas and play

244 a significant role in T2DM development in the examined Russian population. The FTO gene

245 associated with T2DM development in other populations is not associated with the disease in the

246 Russian population. The results do not contradict previous research data, but the different OR

247 values indicate that the contribution of different loci to T2DM development varies among

248 different populations. It should be noted that these data are preliminary and require future

249 confirmation using similar samples in independent studies.

250 The obtained data (OR and allele frequencies for polymorphic markers) will allow the

251 quantitative assessment of the genetic risk of T2DM development in the Russian population.

252 Understanding the genetic basis of disease development allows for better identification of the

253 etiological mutations in the genes that determine susceptibility to T2DM. Understanding the 
254 mechanism underlying T2DM development should allow for development of new medications to

255 protect against the development of this disease in genetically susceptible individuals.

256 We did not use a Bonferroni correction for multiple comparisons, which is a limitation of this

257 study. However, we believe that adequate sample sizes and statistical significance of the

258 comparisons will ensure the high reproducibility of the obtained results in future studies.

260

261

\section{References}

262 1. World Health Organization. Diabetes Country Profiles 2016 [Internet]. Available on URL

263 http://www.who.int/diabetes/country-profiles/en/).

264 2. World Health Organization. Global report on diabetes 2016 [Internet]. Available on

265 URL: http://www.who.int/diabetes/global-report/en/).

266 3. Wang X, Strizich G, Hu Y, Wang T, Kaplan RC, and Qi Q. 2016. Genetic markers of type 2

267 diabetes: Progress in genome-wide association studies and clinical application for risk prediction.

268 J Diabetes 8:24-35. 10.1111/1753-0407.12323

269 4. Hollensted M, Jorgensen ME, Jorgensen T, Ladenvall C, Justesen JM, Karajamaki A, Kriebel

270 J, Rathmann W, Lannfelt L, Lauritzen T, Narisu N, Linneberg A, Melander O, Milani L, Neville

271 M, Orho-Melander M, Qi L, Qi Q, Roden M, Rolandsson O, Swift A, Rosengren AH, Stirrups K, 272 Wood AR, Mihailov E, Blancher C, Carneiro MO, Maguire J, Poplin R, Shakir K, Fennell T,

273 DePristo M, Hrabe de Angelis M, Deloukas P, Gjesing AP, Jun G, Nilsson P, Murphy J, Onofrio

274 R, Thorand B, Hansen T, Meisinger C, Hu FB, Isomaa B, Karpe F, Liang L, Peters A, Huth C,

275 O'Rahilly SP, Palmer CN, Pedersen O, Rauramaa R, Tuomilehto J, Salomaa V, Watanabe RM,

276 Syvanen AC, Bergman RN, Bharadwaj D, Bottinger EP, Cho YS, Chandak GR, Chan JC, Chia 
277 KS, Daly MJ, Ebrahim SB, Langenberg C, Elliott P, Jablonski KA, Lehman DM, Jia W, Ma RC,

278 Pollin TI, Sandhu M, Tandon N, Froguel P, Barroso I, Teo YY, Zeggini E, Loos RJ, Small KS,

279 Ried JS, DeFronzo RA, Grallert H, Glaser B, Metspalu A, Wareham NJ, Walker M, Banks E,

280 Gieger C, Ingelsson E, Im HK, Illig T, Franks PW, Buck G, Trakalo J, Buck D, Prokopenko I,

281 Magi R, Lind L, Farjoun Y, Owen KR, Gloyn AL, Strauch K, Tuomi T, Kooner JS, Lee JY, Park

282 T, Donnelly P, Morris AD, Hattersley AT, Bowden DW, Collins FS, Atzmon G, Chambers JC,

283 Spector TD, Laakso M, Strom TM, Bell GI, Blangero J, Duggirala R, Tai ES, McVean G, Hanis

284 CL, Wilson JG, Seielstad M, Frayling TM, Meigs JB, Cox NJ, Sladek R, Lander ES, Gabriel S,

285 Burtt NP, Mohlke KL, Meitinger T, Groop L, Abecasis G, Florez JC, Scott LJ, Morris AP, Kang

286 HM, Boehnke M, Altshuler D, and McCarthy MI. 2016. The genetic architecture of type 2

287 diabetes. Nature 536:41-47. 10.1038/nature 18642

288 5. Hara K, Shojima N, Hosoe J, and Kadowaki T. 2014. Genetic architecture of type 2 diabetes.

289 Biochemical and Biophysical Research Communications 452:213-220.

$290 \quad$ 10.1016/j.bbrc.2014.08.012

291 6. Aguilar-Bryan L, and Bryan J. 1999. Molecular biology of adenosine triphosphate-sensitive

292 potassium channels. Endocrine Reviews 20:101-135. 10.1210/edrv.20.2.0361

293 7. Albaqumi M, Alhabib FA, Shamseldin HE, Mohammed F, and Alkuraya FS. 2014. A

294 syndrome of congenital hyperinsulinism and rhabdomyolysis is caused by KCNJ11 mutation.

295 Journal of Medical Genetics 51:271-274. 10.1136/jmedgenet-2013-102085

296 8. Gohar NA, Rabie WA, Sharaf SA, Elsharkawy MM, Mira MF, Tolba AO, and Aly H. 2016.

297 Identification of insulin gene variants in neonatal diabetes. Journal of Maternal-Fetal \& Neonatal

298 Medicine:1-6. 10.1080/14767058.2016.1199674 
299 9. Sakura H, Wat N, Horton V, Millns H, Turner RC, and Ashcroft FM. 1996. Sequence

300 variations in the human Kir6.2 gene, a subunit of the beta-cell ATP-sensitive K-channel: no

301 association with NIDDM in while Caucasian subjects or evidence of abnormal function when

302 expressed in vitro. Diabetologia 39:1233-1236.

303 10. Nichols CG, Koster JC, and Remedi MS. 2007. beta-cell hyperexcitability: from

304 hyperinsulinism to diabetes. Diabetes, obesity \& metabolism 9 Suppl 2:81-88. 10.1111/j.1463-

305 1326.2007.00778.x

306 11. Fajas L, Blanchet E, and Annicotte JS. 2010. CDK4, pRB and E2F1: connected to insulin.

307 Cell Division 5:6. 10.1186/1747-1028-5-6

308 12. Kim SY, and Rane SG. 2011. The Cdk4-E2f1 pathway regulates early pancreas development

309 by targeting Pdx1+ progenitors and Ngn3+ endocrine precursors. Development 138:1903-1912.

$310 \quad 10.1242 / \mathrm{dev} .061481$

311 13. Tschen SI, Dhawan S, Gurlo T, and Bhushan A. 2009. Age-dependent decline in beta-cell

312 proliferation restricts the capacity of beta-cell regeneration in mice. Diabetes 58:1312-1320.

$313 \quad 10.2337 / \mathrm{db} 08-1651$

314 14. Hurst CD, Tomlinson DC, Williams SV, Platt FM, and Knowles MA. 2008. Inactivation of

315 the Rb pathway and overexpression of both isoforms of E2F3 are obligate events in bladder

316 tumours with 6p22 amplification. Oncogene 27:2716-2727. 10.1038/sj.onc.1210934

317 15. Wei FY, Nagashima K, Ohshima T, Saheki Y, Lu YF, Matsushita M, Yamada Y, Mikoshiba

318 K, Seino Y, Matsui H, and Tomizawa K. 2005. Cdk5-dependent regulation of glucose-stimulated

319 insulin secretion. Nature Medicine 11:1104-1108. 10.1038/nm1299 
320 16. Ubeda M, Rukstalis JM, and Habener JF. 2006. Inhibition of cyclin-dependent kinase 5

321 activity protects pancreatic beta cells from glucotoxicity. Journal of Biological Chemistry

$322 \quad 281: 28858-28864.10 .1074 /$ jbc.M604690200

323 17. Dunn MF. 2005. Zinc-ligand interactions modulate assembly and stability of the insulin

324 hexamer -- a review. Biometals 18:295-303. DOI: 10.1007/s10534-005-3685-y

325 18. Smidt K, Larsen A, Bronden A, Sorensen KS, Nielsen JV, Praetorius J, Martensen PM, and

326 Rungby J. 2016. The zinc transporter ZNT3 co-localizes with insulin in INS-1E pancreatic beta

327 cells and influences cell survival, insulin secretion capacity, and ZNT8 expression. Biometals

328 29:287-298. DOI: 10.1007/s10534-016-9915-7

329 19. Diabetes Genetics Initiative of Broad Institute of Harvard, Mit Lund University, Novartis

330 Institutes of BioMedical Research, Saxena R, Voight BF, Lyssenko V, Burtt NP, de Bakker PI,

331 Chen H, Roix JJ, Kathiresan S, Hirschhorn JN, Daly MJ, Hughes TE, Groop L, Altshuler D,

332 Almgren P, Florez JC, Meyer J, Ardlie K, Bengtsson Bostrom K, Isomaa B, Lettre G, Lindblad

333 U, Lyon HN, Melander O, Newton-Cheh C, Nilsson P, Orho-Melander M, Rastam L, Speliotes

334 EK, Taskinen MR, Tuomi T, Guiducci C, Berglund A, Carlson J, Gianniny L, Hackett R, Hall L,

335 Holmkvist J, Laurila E, Sjogren M, Sterner M, Surti A, Svensson M, Svensson M, Tewhey R,

336 Blumenstiel B, Parkin M, Defelice M, Barry R, Brodeur W, Camarata J, Chia N, Fava M,

337 Gibbons J, Handsaker B, Healy C, Nguyen K, Gates C, Sougnez C, Gage D, Nizzari M, Gabriel

338 SB, Chirn GW, Ma Q, Parikh H, Richardson D, Ricke D, and Purcell S. 2007. Genome-wide

339 association analysis identifies loci for type 2 diabetes and triglyceride levels. Science 316:1331-

340 1336. DOI: $10.1126 /$ science. 1142358

341 20. Horikawa Y, Miyake K, Yasuda K, Enya M, Hirota Y, Yamagata K, Hinokio Y, Oka Y,

342 Iwasaki N, Iwamoto Y, Yamada Y, Seino Y, Maegawa H, Kashiwagi A, Yamamoto K, 
343 Tokunaga K, Takeda J, and Kasuga M. 2008. Replication of genome-wide association studies of

344 type 2 diabetes susceptibility in Japan. Journal of Clinical Endocrinology and Metabolism

345 93:3136-3141. DOI: 10.1210/jc.2008-0452

346 21. Ng MC, Park KS, Oh B, Tam CH, Cho YM, Shin HD, Lam VK, Ma RC, So WY, Cho YS,

347 Kim HL, Lee HK, Chan JC, and Cho NH. 2008. Implication of genetic variants near TCF7L2,

348 SLC30A8, HHEX, CDKAL1, CDKN2A/B, IGF2BP2, and FTO in type 2 diabetes and obesity in

349 6,719 Asians. Diabetes 57:2226-2233. DOI: 10.2337/db07-1583

350 22. Stratigopoulos G, Padilla SL, LeDuc CA, Watson E, Hattersley AT, McCarthy MI, Zeltser

351 LM, Chung WK, and Leibel RL. 2008. Regulation of Fto/Ftm gene expression in mice and

352 humans. American Journal of Physiology: Regulatory, Integrative and Comparative Physiology

353 294:R1185-1196. DOI: 10.1152/ajpregu.00839.2007

354 23. Kloting N, Schleinitz D, Ruschke K, Berndt J, Fasshauer M, Tonjes A, Schon MR, Kovacs P,

355 Stumvoll M, and Bluher M. 2008. Inverse relationship between obesity and FTO gene expression

356 in visceral adipose tissue in humans. Diabetologia 51:641-647. DOI: 10.1007/s00125-008-09283579

358 24. Matthews DR, Hosker JP, Rudenski AS, Naylor BA, Treacher DF, and Turner RC. 1985.

359 Homeostasis model assessment: insulin resistance and beta-cell function from fasting plasma

360 glucose and insulin concentrations in man. Diabetologia 28:412-419.

361 25. Johns MB, Jr., and Paulus-Thomas JE. 1989. Purification of human genomic DNA from

362 whole blood using sodium perchlorate in place of phenol. Analytical Biochemistry 180:276-278.

363 26. WEB-Calculator to analyze the statistics in "case-control" studies. Available on URL:

364 http://gen-exp.ru/calculator_or.php. 
365 27. Barrett JC, Fry B, Maller J, and Daly MJ. 2005. Haploview: analysis and visualization of LD

366 and haplotype maps. Bioinformatics 21:263-265. DOI: 10.1093/bioinformatics/bth457

367 28. Lewis CM. 2002. Genetic association studies: design, analysis and interpretation. Briefings

368 in Bioinformatics 3:146-153.

369 29. Scott LJ, Mohlke KL, Bonnycastle LL, Willer CJ, Li Y, Duren WL, Erdos MR, Stringham

370 HM, Chines PS, Jackson AU, Prokunina-Olsson L, Ding CJ, Swift AJ, Narisu N, Hu T, Pruim R, 371 Xiao R, Li XY, Conneely KN, Riebow NL, Sprau AG, Tong M, White PP, Hetrick KN, Barnhart

372 MW, Bark CW, Goldstein JL, Watkins L, Xiang F, Saramies J, Buchanan TA, Watanabe RM,

373 Valle TT, Kinnunen L, Abecasis GR, Pugh EW, Doheny KF, Bergman RN, Tuomilehto J,

374 Collins FS, and Boehnke M. 2007. A genome-wide association study of type 2 diabetes in Finns

375 detects multiple susceptibility variants. Science 316:1341-1345. DOI: 10.1126/science.1142382

376 30. Salonen JT, Uimari P, Aalto JM, Pirskanen M, Kaikkonen J, Todorova B, Hypponen J,

377 Korhonen VP, Asikainen J, Devine C, Tuomainen TP, Luedemann J, Nauck M, Kerner W,

378 Stephens RH, New JP, Ollier WE, Gibson JM, Payton A, Horan MA, Pendleton N, Mahoney W,

379 Meyre D, Delplanque J, Froguel P, Luzzatto O, Yakir B, and Darvasi A. 2007. Type 2 diabetes

380 whole-genome association study in four populations: the DiaGen consortium. American Journal

381 of Human Genetics 81:338-345. DOI: 10.1086/520599

382 31. Shaat N, Ekelund M, Lernmark A, Ivarsson S, Almgren P, Berntorp K, and Groop L. 2005.

383 Association of the E23K polymorphism in the KCNJ11 gene with gestational diabetes mellitus.

384 Diabetologia 48:2544-2551. DOI: $10.1007 / \mathrm{s} 00125-005-0035-0$

385 32. Florez JC, Jablonski KA, Kahn SE, Franks PW, Dabelea D, Hamman RF, Knowler WC,

386 Nathan DM, and Altshuler D. 2007. Type 2 diabetes-associated missense polymorphisms

$387 \mathrm{KCNJ} 11 \mathrm{E} 23 \mathrm{~K}$ and $\mathrm{ABCC} 8 \mathrm{~A} 1369 \mathrm{~S}$ influence progression to diabetes and response to 
388 interventions in the Diabetes Prevention Program. Diabetes 56:531-536. DOI: 10.2337/db063890966

390 33. Sakamoto Y, Inoue H, Keshavarz P, Miyawaki K, Yamaguchi Y, Moritani M, Kunika K,

391 Nakamura N, Yoshikawa T, Yasui N, Shiota H, Tanahashi T, and Itakura M. 2007. SNPs in the

392 KCNJ11-ABCC8 gene locus are associated with type 2 diabetes and blood pressure levels in the

393 Japanese population. Journal of Human Genetics 52:781-793. DOI: 10.1007/s10038-007-0190-x

394 34. Gonen MS, Arikoglu H, Erkoc Kaya D, Ozdemir H, Ipekci SH, Arslan A, Kayis SA, and

395 Gogebakan B. 2012. Effects of single nucleotide polymorphisms in K(ATP) channel genes on

396 type 2 diabetes in a Turkish population. Archives of Medical Research 43:317-323. DOI:

397 10.1016/j.arcmed.2012.06.001

398 35. Iwata M, Maeda S, Kamura Y, Takano A, Kato H, Murakami S, Higuchi K, Takahashi A, 399 Fujita H, Hara K, Kadowaki T, and Tobe K. 2012. Genetic risk score constructed using 14

400 susceptibility alleles for type 2 diabetes is associated with the early onset of diabetes and may

401 predict the future requirement of insulin injections among Japanese individuals. Diabetes Care

402 35:1763-1770. DOI: $10.2337 / \mathrm{dc} 11-2006$

403 36. Odgerel Z, Lee HS, Erdenebileg N, Gandbold S, Luvsanjamba M, Sambuughin N,

404 Sonomtseren S, Sharavdorj P, Jodov E, Altaisaikhan K, and Goldfarb LG. 2012. Genetic variants

405 in potassium channels are associated with type 2 diabetes in a Mongolian population. J Diabetes

406 4:238-242. DOI: 10.1111/j.1753-0407.2011.00177.x

407 37. Phani NM, Guddattu V, Bellampalli R, Seenappa V, Adhikari P, Nagri SK, SC DS, Mundyat 408 GP, Satyamoorthy K, and Rai PS. 2014. Population specific impact of genetic variants in

409 KCNJ11 gene to type 2 diabetes: a case-control and meta-analysis study. PloS One 9:e107021.

410 DOI: 10.1371/journal.pone.0107021 
411 38. Florez JC, Burtt N, de Bakker PI, Almgren P, Tuomi T, Holmkvist J, Gaudet D, Hudson TJ,

412 Schaffner SF, Daly MJ, Hirschhorn JN, Groop L, and Altshuler D. 2004. Haplotype structure and

413 genotype-phenotype correlations of the sulfonylurea receptor and the islet ATP-sensitive

414 potassium channel gene region. Diabetes 53:1360-1368.

415 39. Nielsen EM, Hansen L, Carstensen B, Echwald SM, Drivsholm T, Glumer C, Thorsteinsson

416 B, Borch-Johnsen K, Hansen T, and Pedersen O. 2003. The E23K variant of Kir6.2 associates

417 with impaired post-OGTT serum insulin response and increased risk of type 2 diabetes. Diabetes $418 \quad 52: 573-577$.

419 40. Boesgaard TW, Zilinskaite J, Vanttinen M, Laakso M, Jansson PA, Hammarstedt A, Smith

420 U, Stefan N, Fritsche A, Haring H, Hribal M, Sesti G, Zobel DP, Pedersen O, Hansen T, and

421 Consortium E. 2008. The common SLC30A8 Arg325Trp variant is associated with reduced first422 phase insulin release in 846 non-diabetic offspring of type 2 diabetes patients--the EUGENE2 423 study. Diabetologia 51:816-820. DOI: 10.1007/s00125-008-0955-6

424 41. Kirchhoff K, Machicao F, Haupt A, Schafer SA, Tschritter O, Staiger H, Stefan N, Haring 425 HU, and Fritsche A. 2008. Polymorphisms in the TCF7L2, CDKAL1 and SLC30A8 genes are 426 associated with impaired proinsulin conversion. Diabetologia 51:597-601. DOI: 10.1007/s00125$427 \quad 008-0926-y$

428 42. Ferru A, Fromont G, Gibelin H, Guilhot J, Savagner F, Tourani JM, Kraimps JL, Larsen CJ, 429 and Karayan-Tapon L. 2006. The status of CDKN2A alpha (p16INK4A) and beta (p14ARF) 430 transcripts in thyroid tumour progression. British Journal of Cancer 95:1670-1677. DOI:

$431 \quad 10.1038 /$ sj.bjc. 6603479 
432 43. Kong X, Xing X, Hong J, Zhang X, and Yang W. 2016. Genetic variants associated with lean

433 and obese type 2 diabetes in a Han Chinese population: A case-control study. Medicine

434 (Baltimore) 95:e3841. DOI: 10.1097/MD.0000000000003841

435 44. Lewis JP, Palmer ND, Hicks PJ, Sale MM, Langefeld CD, Freedman BI, Divers J, and

436 Bowden DW. 2008. Association analysis in african americans of European-derived type 2

437 diabetes single nucleotide polymorphisms from whole-genome association studies. Diabetes

438 57:2220-2225. DOI: $10.2337 / \mathrm{db} 07-1319$

439 45. Omori S, Tanaka Y, Takahashi A, Hirose H, Kashiwagi A, Kaku K, Kawamori R, Nakamura

440 Y, and Maeda S. 2008. Association of CDKAL1, IGF2BP2, CDKN2A/B, HHEX, SLC30A8,

441 and KCNJ11 with susceptibility to type 2 diabetes in a Japanese population. Diabetes 57:791-

442 795. DOI: $10.2337 / \mathrm{db} 07-0979$

443 46. Grarup N, Rose CS, Andersson EA, Andersen G, Nielsen AL, Albrechtsen A, Clausen JO,

444 Rasmussen SS, Jorgensen T, Sandbaek A, Lauritzen T, Schmitz O, Hansen T, and Pedersen O.

445 2007. Studies of association of variants near the HHEX, CDKN2A/B, and IGF2BP2 genes with

446 type 2 diabetes and impaired insulin release in 10,705 Danish subjects: validation and extension

447 of genome-wide association studies. Diabetes 56:3105-3111. DOI: $10.2337 / \mathrm{db} 07-0856$

448 47. Cauchi S, Meyre D, Durand E, Proenca C, Marre M, Hadjadj S, Choquet H, De Graeve F,

449 Gaget S, Allegaert F, Delplanque J, Permutt MA, Wasson J, Blech I, Charpentier G, Balkau B,

450 Vergnaud AC, Czernichow S, Patsch W, Chikri M, Glaser B, Sladek R, and Froguel P. 2008.

451 Post genome-wide association studies of novel genes associated with type 2 diabetes show gene-

452 gene interaction and high predictive value. PloS One 3:e2031. DOI:

453 10.1371/journal.pone.0002031 
454 48. van Hoek M, Dehghan A, Witteman JC, van Duijn CM, Uitterlinden AG, Oostra BA, 455 Hofman A, Sijbrands EJ, and Janssens AC. 2008. Predicting type 2 diabetes based on 456 polymorphisms from genome-wide association studies: a population-based study. Diabetes 457 57:3122-3128. DOI: 10.2337/db08-0425

458 49. Dehwah MA, Wang M, and Huang QY. 2010. CDKAL1 and type 2 diabetes: a global meta459 analysis. Genetics and Molecular Research 9:1109-1120. DOI: 10.4238/vol9-2gmr802

460 50. Pascoe L, Tura A, Patel SK, Ibrahim IM, Ferrannini E, Zeggini E, Weedon MN, Mari A,

461 Hattersley AT, McCarthy MI, Frayling TM, Walker M, Consortium R, and Consortium UKTDG.

462 2007. Common variants of the novel type 2 diabetes genes CDKAL1 and HHEX/IDE are 463 associated with decreased pancreatic beta-cell function. Diabetes 56:3101-3104. DOI:

$464 \quad 10.2337 / \mathrm{db} 07-0634$

465 51. Wen J, Ronn T, Olsson A, Yang Z, Lu B, Du Y, Groop L, Ling C, and Hu R. 2010.

466 Investigation of type 2 diabetes risk alleles support CDKN2A/B, CDKAL1, and TCF7L2 as

467 susceptibility genes in a Han Chinese cohort. PloS One 5:e9153. DOI:

468 10.1371/journal.pone.0009153

469 52. Hu C, Zhang R, Wang C, Wang J, Ma X, Lu J, Qin W, Hou X, Wang C, Bao Y, Xiang K, 470 and Jia W. 2009. PPARG, KCNJ11, CDKAL1, CDKN2A-CDKN2B, IDE-KIF11-HHEX,

471 IGF2BP2 and SLC30A8 are associated with type 2 diabetes in a Chinese population. PloS One 472 4:e7643. DOI: 10.1371/journal.pone.0007643

473 53. Tabara Y, Osawa H, Kawamoto R, Onuma H, Shimizu I, Miki T, Kohara K, and Makino H. 474 2009. Replication study of candidate genes associated with type 2 diabetes based on genome475 wide screening. Diabetes 58:493-498. DOI: 10.2337/db07-1785 
476 54. Rong R, Hanson RL, Ortiz D, Wiedrich C, Kobes S, Knowler WC, Bogardus C, and Baier

477 LJ. 2009. Association analysis of variation in/near FTO, CDKAL1, SLC30A8, HHEX, EXT2,

478 IGF2BP2, LOC387761, and CDKN2B with type 2 diabetes and related quantitative traits in

479 Pima Indians. Diabetes 58:478-488. DOI: 10.2337/db08-0877

480 55. Gerken T, Girard CA, Tung YC, Webby CJ, Saudek V, Hewitson KS, Yeo GS, McDonough

481 MA, Cunliffe S, McNeill LA, Galvanovskis J, Rorsman P, Robins P, Prieur X, Coll AP, Ma M,

482 Jovanovic Z, Farooqi IS, Sedgwick B, Barroso I, Lindahl T, Ponting CP, Ashcroft FM, O'Rahilly

483 S, and Schofield CJ. 2007. The obesity-associated FTO gene encodes a 2-oxoglutarate-dependent

484 nucleic acid demethylase. Science 318:1469-1472. DOI: 10.1126/science.1151710

485 56. De Luis DA, Aller R, Izaola O, Primo D, and Romero E. 2016. Association of the rs9939609

486 gene variant in FTO with insulin resistance, cardiovascular risk factor and serum adipokine

487 levels in obese patients. Nutricion Hospitalaria 33:573. DOI: 10.20960/nh.573

488 57. Livingstone KM, Celis-Morales C, Papandonatos GD, Erar B, Florez JC, Jablonski KA,

489 Razquin C, Marti A, Heianza Y, Huang T, Sacks FM, Svendstrup M, Sui X, Church TS,

490 Jaaskelainen T, Lindstrom J, Tuomilehto J, Uusitupa M, Rankinen T, Saris WH, Hansen T,

491 Pedersen O, Astrup A, Sorensen TI, Qi L, Bray GA, Martinez-Gonzalez MA, Martinez JA,

492 Franks PW, McCaffery JM, Lara J, and Mathers JC. 2016. FTO genotype and weight loss:

493 systematic review and meta-analysis of 9563 individual participant data from eight randomised

494 controlled trials. BMJ 354:i4707. DOI: 10.1136/bmj.i4707

495 58. Munoz-Yanez C, Perez-Morales R, Moreno-Macias H, Calleros-Rincon E, Ballesteros G,

496 Gonzalez RA, and Espinosa J. 2016. Polymorphisms FTO rs9939609, PPARG rs1801282 and

497 ADIPOQ rs4632532 and rs182052 but not lifestyle are associated with obesity related-traits in 
498 Mexican children. Genetics and Molecular Biology 39:547-553. DOI: 10.1590/1678-4685-

499 GMB-2015-0267

500 59. Moraes GG, Reuter CP, Renner JD, Klinger EI, Ferreira MB, Mello ED, Valim AM, and

501 Burgos MS. 2016. Genotypic carriers of the obesity-associated FTO polymorphism exhibit

502 different cardiometabolic profiles after an intervention. Anais da Academia Brasileira de

503 Ciências 88:2331-2339. DOI: 10.1590/0001-3765201620160114

504 60. Chen EY, Olino TM, Conklin CJ, Mohamed FB, Hoge WS, Foster GD, Genetic, Neural

505 Biomarkers of Obesity study group, Arlt JM, Eneva K, Kidd JR, Kidd KR, Lent MR, Murray S,

506 Newberg A, Tewksbury C, VanderVeur SS, and Yiu A. 2017. Genetic and and neural predictors

507 of behavioral weight loss treatment: A preliminary study. Obesity (Silver Spring) 25:66-75. DOI:

$508 \quad 10.1002 /$ oby.21691

509 61. Wahlen K, Sjolin E, and Hoffstedt J. 2008. The common rs9939609 gene variant of the fat

510 mass- and obesity-associated gene FTO is related to fat cell lipolysis. Journal of Lipid Research

511 49:607-611. DOI: 10.1194/jlr.M700448-JLR200

512 62. Hinney A, Nguyen TT, Scherag A, Friedel S, Bronner G, Muller TD, Grallert H, Illig T,

513 Wichmann HE, Rief W, Schafer H, and Hebebrand J. 2007. Genome wide association (GWA)

514 study for early onset extreme obesity supports the role of fat mass and obesity associated gene

515 (FTO) variants. PloS One 2:e1361. DOI: 10.1371/journal.pone.0001361. 